\title{
CONSTITUTIVE AND INDUCIBLE PECTINOLYTIC ENZYMES FROM ASPERGILLUS FLAVIPES FP-500 AND THEIR MODULATION BY PH AND CARBON SOURCE
}

\author{
Aurora Martínez-Trujillo ${ }^{1,2}$; Juan S. Aranda² ; Carlos Gómez-Sánchez ${ }^{3}$; Blanca Trejo-Aguilar³; \\ Guillermo Aguilar-Osorio ${ }^{3 *}$
}

\begin{abstract}
${ }^{1}$ Laboratory of Enzymatic Catalysis, Technologic Institute for Higher Studies of Ecatepec, Ecatepec, Estado de Mexico; ${ }^{2}$ Department of Bioengineering, Professional Unit of Biotechnology, National Polytechnic Institute of Mexico, UPIBI-IPN, Col. La Laguna Ticoman, D.F., Mexico; ${ }^{3}$ Department of Food Science and Biotechnology, Faculty of Chemistry, National University of Mexico, Ciudad Universitaria, D.F., Mexico.
\end{abstract}

Submitted: November 28, 2007; Returned to authors for corrections: July 09, 2008; Approved: February 15, 2009.

\begin{abstract}
Growth and enzymes production by Aspergillus flavipes FP-500 were evaluated on pectin, polygalacturonic acid, galacturonic acid, arabinose, rhamnose, xylose, glycerol and glucose at different initial $\mathrm{pH}$ values. We found that the strain produced exopectinases, endopectinases and pectin lyases. Exopectinases and pectin lyase were found to be produced at basal levels as constitutive enzymes and their production was modulated by the available carbon source and $\mathrm{pH}$ of culture medium and stimulated by the presence of inducer in the culture medium. Endo-pectinase was basically inducible and was only produced when pectin was used as carbon source. Our results suggest that pectinases in A. flavipes FP-500 are produced in a concerted way. The first enzyme to be produced was exopectinase followed by Pectin Lyase and Endo-pectinase.
\end{abstract}

Keywords: Aspergillus flavipes, pectinolytic enzymes, constitutive enzymes, inducible enzymes, pectin.

\section{INTRODUCTION}

Pectin is composed of distinct polysaccharides fractions, such as homogalacturonan (HG), xylogalacturonan (XGA), rhamnogalacturonan I (RGI) and rhamnogalacturonan II (RGII). HG is known as the "smooth region" of pectin, it is a linear polymer composed of 1,4-linked $\alpha$-D-galacturonic acid residues. Some of these residues can be, to different extent, methylesterified at the carboxylic acid group (C6 position) and/or can carry acetyl groups on C-2 and C-3. In XGA $\beta$-D-xylose residues are $\beta$-(1,3)-linked to the galacturonyl residue of the $\mathrm{HG}$ backbone. RGI is composed of alternating $\alpha$-(1,2)-linked rhamnosyl and $\alpha-(1-4)$-linked galactosyluronic acid residues. The rhamnosyl residues are branched with O-4 attached neutral sugars side chains that can vary from a single galactose residue up to polymeric chains of glycosyl residues composed of arabinose (arabinan side chains) and/or arabinose and galactose residues (arabinogalactan side chains). RGII is comprised of a backbone of approximately nine $\alpha$ - $(1,4)$-linked Dgalactosyluronic acid residues that carry four side chains. Which consist of a number of rare sugars such as apiose, fucose, aceric acid and other. XGA, RGI and RGII are part of the branched region of pectin also known as "hairy region" $(5,21)$.

The complex and heterogeneous structure of pectin has implications regarding the enzymes involved in its degradation and requires the presence of many different enzymatic activities. The main-chain-degrading enzymes are classified into esterases and depolymerases. The latter are divided into hydrolases (exo and endo types) and lyases (pectin and pectate). On the one hand, hydrolases (EC 3.2.1.15, EC 3.2.1.67 and EC 3.2.1.82) incorporate a water molecule via general acid catalysis during the cleavage of the glycosidic bond between the two saccharide units. On the other, lyases (EC 4.2.2.2, EC 4.2.2.9 and EC 4.2.2.10) cleave the glycosidic bond via a $\beta$-elimination reaction that removes a proton, resulting in an unsaturated bond between $\mathrm{C}$ 4 and $\mathrm{C}-5$ of the saccharide unit at the nonreducing end $(5,6)$.

*Corresponding Author. Mailing address: Department of Food Science and Biotechnology, Faculty of Chemistry, National University of Mexico, Ciudad Universitaria, Conj. E, Quimica, CP 04510, Mexico, D.F. Tel.: (525) 5 5622-5306 Fax: (525) 5 5622-5309. E-mail: gao@ servidor.unam.mx 
Pectin-degrading enzymes are widely used in a number of industries, including food processing, textile industry, wastewater treatment, animal feed, pulp and paper industry, among others $(9,17)$. In addition, the understanding of the regulation process of the production of polygalacturonases will contribute not only to improve enzyme production, but also to get insights in the molecular dialogue between the host and the pathogen, during the microbial invasion of plant cell wall $(7,11,22)$.

Pectin-degrading enzymes are produced by many microorganisms. Among them, Aspergillus species are widely used to produce a large number of enzymes from a great variety of carbon sources (24). Since Aspergillus, as is the case of other microorganisms, is not able to import polysaccharides, it has been proposed that mono or oligosaccharides released from the polymers at early stages of fungal growth, actually trigger expression of the degrading enzymes (13). Moreover, it is generally accepted that in Aspergillus niger, D-galacturonic acid or a metabolite derived from it is acting as an inducer of at least 12 pectinolytic genes (3). However, there are other subsets of pectinolytic genes responding to the presence of $\mathrm{L}$-arabinose, L-rhamnose and ferulic acid (3). Pectinase expression is closely related to the carbon source available $(2,18,26)$. Evidence for $\mathrm{pH}$-dependent expression of pectinolytic genes has also been pointed out for some Aspergillus strains $(5,20,22)$.

The aim of this study was to elucidate the constitutive or inducible nature of pectin degrading enzymes produced by Asperigillus flavipes FP-500 and to evaluate the effect of initial $\mathrm{pH}$ of culture medium on growth and pectinase production.

\section{MATERIALS AND METHODS}

\section{Microorganism}

The microorganism used in this work was the white fungus Aspergillus flavipes FP-500, which produces extracellular pectinolytic activities at $37^{\circ} \mathrm{C}$. The microorganism was maintained and propagated on potato dextrose agar plates.

\section{Preparation of inoculum}

The inoculum for either flasks or fermentor was prepared by growing the strain on PDA plates during 3 days at $37^{\circ} \mathrm{C}$. After this time spores were harvested by addition of $10 \mathrm{ml}$ of salinetween solution $(\mathrm{NaCl}, 0.9 \%$ and Tween $80,0.01 \%)$ per plate. The spore suspension was counted in a counting chamber microscopic cell (American Optical, Inc. USA) and diluted with the same solution so that a final concentration of $1 \times 10^{6}$ spores $\mathrm{ml}^{-1}$ of culture medium was reached.

\section{Media and fermentation conditions}

For the production of pectinolytic activity, shake flasks and bioreactor experiments were conducted. Firstly, for shake flasks experiments $500 \mathrm{ml}$ Erlenmeyer flaks were used, each one containing $100 \mathrm{ml}$ of culture medium, and were agitated at 200 rpm in a reciprocant incubator shaker (Newbrunswick Sci. Co., USA) maintained at $37^{\circ} \mathrm{C}$. Secondly, bioreactor experiments were conducted in a Bioflo 110 bioreactor (Newbrunswick Sci. Co., USA) filled with $5.0 \mathrm{~L}$ of culture medium. Sterile air was supplied at a rate $0.5 \mathrm{vvm}$ and the agitation speed was $200 \mathrm{rpm}$. Temperature was maintained at $37^{\circ} \mathrm{C}$.

Basal medium used contained $\left(\mathrm{g} \mathrm{l}^{-1}\right): \mathrm{K}_{2} \mathrm{HPO}_{4}, 2 ; \mathrm{KH}_{2} \mathrm{PO}_{4}, 2$; and $\left(\mathrm{NH}_{4}\right)_{2} \mathrm{SO}_{4}, 5$ and was supplemented with the chosen carbon source. Citrus pectin (P), polygalacturonic acid (PGA), galacturonic acid(GalA), arabinose (Ara), rhamnose(Rha), xylose (Xyl), glucose (Glc) and glycerol (Gly) (Sigma-Aldrich, Co., USA) all at $10 \mathrm{gl}^{-1}$ were used as carbon sources. When simple sugars or glycerol were used $0.1 \%$ of yeast extract was added. Sterilization was carried out at $121^{\circ} \mathrm{C}$ and $15 \mathrm{psi}$ for $20 \mathrm{~min}$. The initial $\mathrm{pH}$ of the medium was adjusted to $3.5,4.2$ and 5.0 with $2 \mathrm{M}$ $\mathrm{NaOH}$ or $\mathrm{H}_{2} \mathrm{SO}_{4}$.

\section{Cell growth}

Cell growth was measured as dry weight (DW). After filtering the sample through a Millipore membrane (pore size $5.0 \mu \mathrm{m}$, Millipore Mexico, S.A. de C.V.), previously dried to constant weight, the retained cell mass was dried at $80^{\circ} \mathrm{C}$ until constant weight was reached.

\section{Assays for pectinolytic activity}

Samples were taken from flasks or fermentor at various times during fermentation and were immediately filtered through Millipore membrane. Pectinolytic activity of these cell-free samples was determined. Exo-pectinolytic (Exo-PG)activity was measured by quantifying the concentration of reducing groups which had been liberated after incubation $\left(45^{\circ} \mathrm{C}, 20 \mathrm{~min}\right)$ with $1 \%$ pectin $(\mathrm{w} / \mathrm{v})$ in $50 \mathrm{mM}$ acetate buffer at $\mathrm{pH}$ 5.0. One Unit of exo-pectinolytic activity was defined as the amount of enzyme that catalyzes the formation of $1 \mu \mathrm{mol}$ of galaturonic acid under assay conditions (25). For endopolygalacturonase (Endo-PG), by measuring the relative change in viscosity of $1 \%$ pectin in 16 $\mathrm{mM}$ acetate buffer added with $41 \mathrm{mM} \mathrm{NaCl}$ at $30^{\circ} \mathrm{C}$ in a Canon Fenske 200 viscosimeter. One Unit of endopolygalacturonase activity was defined as the amount of enzyme that reduced the viscosity of $10 \mathrm{ml}$ of pectin by $50 \%$ in $10 \mathrm{~min}$ at $\mathrm{pH} 4.2$ under the assay conditions (25). Pectin-lyase (PL) activity was measured by monitoring the increase in absorbance at $235 \mathrm{~nm}$ brought about by the appearance of the double bond between carbon atoms 4 and 5 of galacturonic acid. We used a modification of the technique proposed by Delgado et al. (6). Briefly, the reaction mixture contained $1.0 \mathrm{ml}$ of $1 \%$ pectin in $50 \mathrm{mM}$ TRIS-acetate buffer $\mathrm{pH} 8.8$, and $0.2 \mathrm{ml}$ of cell-free sample. Incubation was carried out at $40^{\circ} \mathrm{C}$ for $1 \mathrm{~h}$, after this time $0.2 \mathrm{ml}$ aliquot was taken from the reaction mixture and added to a test tube containing $1.8 \mathrm{ml}$ of $10 \mathrm{mM} \mathrm{HCl}$ to stop the reaction. One Unit of pectin lyase activity was defined as the amount of enzyme that causes 
an increase of 0.1 units of the absorbance at $235 \mathrm{~nm}$, under assay conditions.

\section{Reducing sugars concentration}

Reducing sugars were analyzed using 3,5-dinitrosalicilic acid (DNS) method (15) with the appropriate sugar as the reference standard.

\section{Statistical analysis}

Treatment effects with triplicated assays were compared by least significant difference (LSD) methodology (16). Thus, statistically significant differences between average values were determined with the $\mathrm{SAS} \AA$ software at a confidence level $\alpha=$ 0.05 .

\section{Pectinases productivity calculation}

Volumetric production rates for biomass $\left(q_{x}\right)$ and enzymatic activities $\left(q_{p E}\right)$ were calculated by:

$q_{x}=\frac{\text { Produced biomass }(X)}{\text { time period }}=\frac{X_{2}-X_{1}}{t_{2}-t_{1}}=\frac{m g \text { dry biomass }}{m l . h}$ and,

$q_{x E}=\frac{\text { Produced enzymatic activity }(E)}{\text { time period }}=\frac{E_{2}-E_{1}}{t_{2}-t_{1}}[=] \frac{U}{m l . h}$

The $q_{p E \text { max }}$ and the corresponding $q_{x}$ were used to obtain the specific enzyme productivity through:

$$
P_{E / X}={\frac{q_{p E, \max }}{q_{x}}}^{[=]} \frac{U}{m g \text { dry biomass }}
$$

\section{RESULTS}

\section{Pectinases produced by Aspergillus flavipes FP-500 growing} on pectin at different initial $\mathbf{p H}$ conditions

Initial $\mathrm{pH}$ was evaluated on shake flasks and at bioreactor level. As it can be seen in Fig.1, when shake flasks experiments were conducted, cell growth of A. flavipes FP-500 on pectin reached a maximum of $4.5 \mathrm{mg} \mathrm{ml}^{-1}$ at an initial $\mathrm{pH}$ of 5.0. Lower growth, around $3 \mathrm{mg} \mathrm{ml}^{-1}$, was attained at the other $\mathrm{pH}$ values (Fig. 1A).

Despite the lower cell growth attained at $\mathrm{pH} 3.5$, Exo-PG production was higher in relation to other $\mathrm{pH}$ values tested and in fact, the difference was quite clear since early stages of fermentation (Fig. 1B). At $24 \mathrm{~h}$ when the initial $\mathrm{pH}$ was 3.5 ExoPG activity represented around 3.8 times higher than that obtained at pH 4.2 (Fig. 1B). A similar result was obtained for Endo-PG production, which was also higher at $\mathrm{pH} 3.5$ (Fig. 1C). However, the difference at the distinct $\mathrm{pH}$ values was more evident at later fermentation time. Quite the opposite was observed for PL production. During the first $48 \mathrm{~h}$ of culture, the

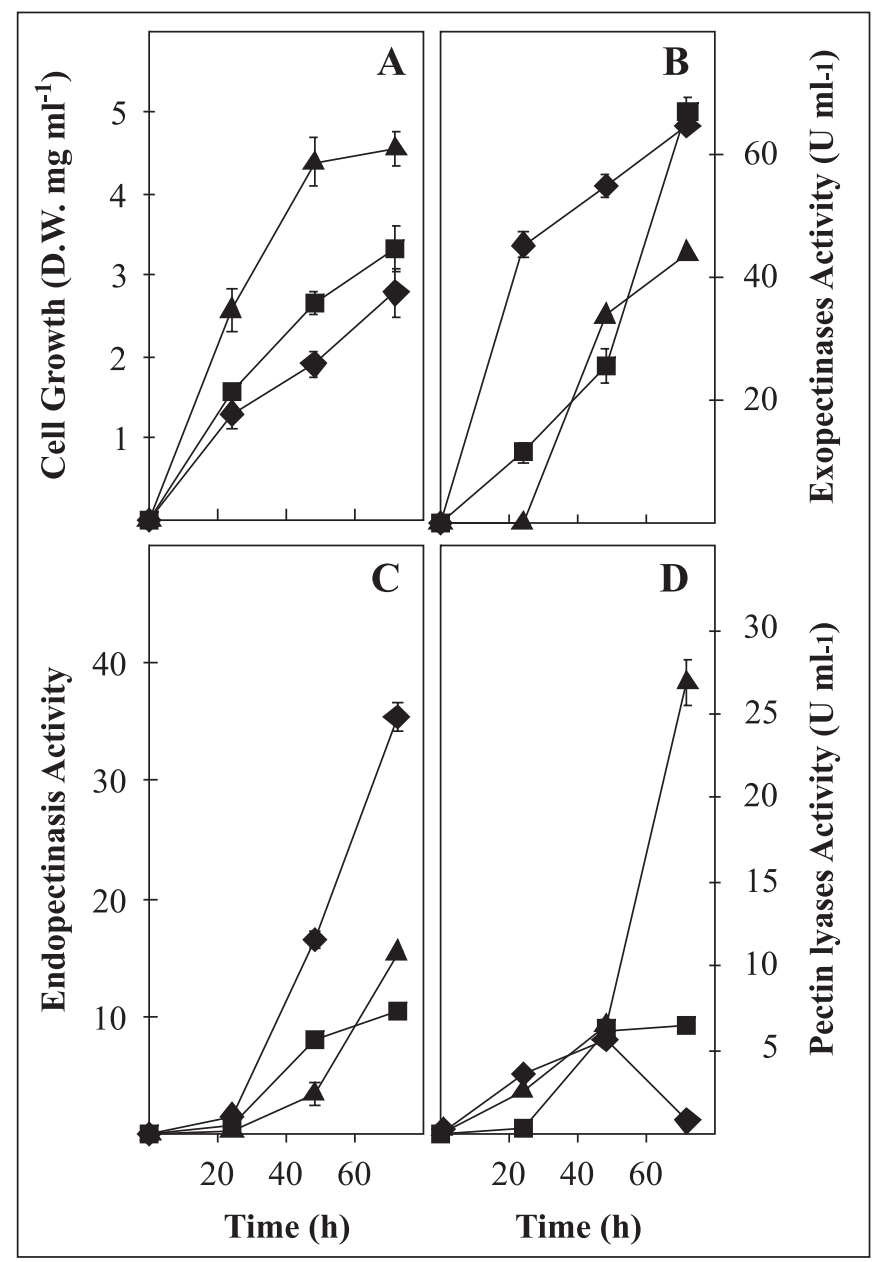

Figure 1. Growth (A), Exo-PG (B), Endo-PG (C) and PL (D) activities produced by Aspergillus flavipes FP-500 growing in shaken flasks with $10 \mathrm{~g} \mathrm{l}^{-1}$ of pectin at initial $\mathrm{pH}$ of $3.5(\diamond), 4.2$ (ם) and $5.0(\mathbf{A})$.

activity remained similar irrespective to the $\mathrm{pH}$ of culture medium (Fig. 1D). However, at a later stage (72 h) lyase activity was around 4 times higher when the $\mathrm{pH}$ was 5.0 (Fig. 1D).

According to shake flask experiments, the initial $\mathrm{pH}$ of the medium and its evolution affected the pectinases produced by A. flavipes FP-500. At $5 \mathrm{~L}$ fermentation level it was possible to get more samples during fermentation, so that a better picture of the evolution of the fermentation was obtained. As can be seen from Fig. 2, at early stages of fermentation pectin was degraded and its products accumulated (Fig. 2A). A maximum was attained between 24 and 36 hours after which a reduction in their concentration was observed. At this level the cell growth evolution was slower than in shaken flask experiments, although a maximum growth was attained at the same $\mathrm{pH}$ value on both systems (data not shown). 


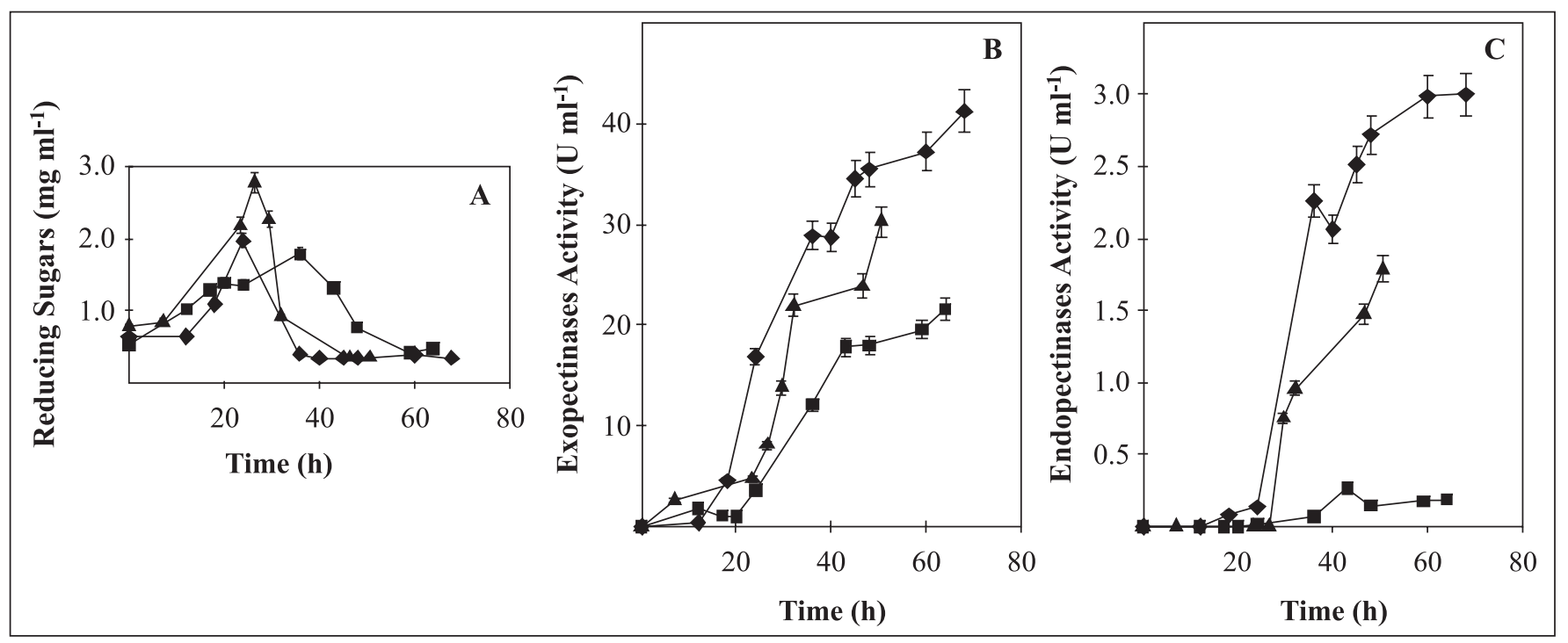

Figure 2. Reducing sugar concentration (A), Exo-PG (B) and Endo-PG activity (C) produced by Aspergillus flavipes FP-500 growing in a $5.0 \mathrm{~L}$ bioreactor with $10 \mathrm{~g} \mathrm{l}^{-1}$ of pectin, at initial $\mathrm{pH}$ of $3.5(\bullet), 4.2(\mathbf{\square})$ and $5.0(\mathbf{\Delta})$.

As a consequence of the reduction on the reducing sugars' concentration, an increase in Exo-PG and Endo-PG activity was observed (Fig. 2A-C). In these experiments, maximum production of both enzymes was attained at $3.5 \mathrm{pH}$ (Fig. $2 \mathrm{~B}$ and $2 \mathrm{C}$ ), in the same way as in the results obtained in shaken flask experiments.

In addition, when the strain grows on pectin, there is subtle change in $\mathrm{pH}$ during the first 24 hours (Fig. 3A). However, after a media acidification in between $24-30 \mathrm{~h}$, culture $\mathrm{pH}$ increased to reach values higher than the initial (Fig. 3A). Exo-PG showed to be modulated by $\mathrm{pH}$ of culture medium. However, a more dramatic influence on EndoPG activity was observed (Fig. 2C) and PL (Fig. 3B). Surprisingly pectin-lyase maximum production was attained at $\mathrm{pH}$ 3.5. This later result was not expected, since on shake flask experiments PL activity was found to be higher at $\mathrm{pH} 5$.

\section{Pectinase production on different carbon sources and pH values}

Growth and production of pectinase by Aspergillus flavipes FP-500 with different carbon sources at three $\mathrm{pH}$ values were carried out in shaken flask cultures. Results are presented in Tables 1-3. Exo-PG was produced practically on all carbon sources, including those not structurally related to pectin, such as glycerol. Moreover, low Exo-PG productivity was measured also in media containing glucose as the only carbon source (Table 1). This fact suggests that ExoPG could be constitutive in A. flavipes FP-500. It should be noted that there is an important difference in the production of Exo-PG with simple sugars and pectin, (i.e at $\mathrm{pH}$ $4.2,3.03 \mathrm{U} \mathrm{mg}^{-1}$ dry biomass and $63.82 \mathrm{U} \mathrm{mg}^{-1}$ dry biomass, were obtained for xylose and pectin, respectively), indicating that the production of the enzyme is also stimulated by the presence of inducers.

Even though, initial $\mathrm{pH}$ had not a clear trend with simple sugars, it seem that the most favorable initial $\mathrm{pH}$ was 3.5 , except

Table 1. Exo-PG productivity of A. flavipes FP-500 in submerged culture using different carbon sources ${ }^{(1)}$.

\begin{tabular}{|c|c|c|c|c|}
\hline \multirow[t]{2}{*}{$\begin{array}{l}\text { Carbon } \\
\text { source }\end{array}$} & \multicolumn{4}{|c|}{$\begin{array}{c}P_{E X X}(\mathrm{U} / \mathrm{mg} \text { dry biomass }) \\
\text { Initial } \mathrm{pH}\end{array}$} \\
\hline & 3.5 & 4.2 & 5.0 & $L S D^{*}$ \\
\hline Arabinose & $1.50 \pm 0.042$ & $7.37 \pm 0.21$ & $3.17 \pm 0.092$ & 0.0338 \\
\hline Galacturonic acid & $7.85 \pm 0.39$ & $0.78 \pm 0.04$ & $5.10 \pm 0.26$ & 0.5418 \\
\hline Glucose & $0.25 \pm 0.042$ & $0.52 \pm 0.21$ & $0.36 \pm 0.092$ & 0.0392 \\
\hline Glycerol & $7.28 \pm 0.360$ & $5.5 \pm 0.08$ & $2.83 \pm 0.14$ & 0.4595 \\
\hline Pectin & $34.95 \pm 1.75$ & $63.82 \pm 3.2$ & $18.68 \pm 0.94$ & 4.3327 \\
\hline $\begin{array}{l}\text { Polygalacturonic } \\
\text { acid }\end{array}$ & $5.21 \pm 0.26$ & $24.54 \pm 1.23$ & $12.44 \pm 0.62$ & 1.6150 \\
\hline Rhamnose & $1.09 \pm 0.05$ & $12.92 \pm 0.65$ & $1.59 \pm 0.08$ & 0.7543 \\
\hline Xylose & $0.16 \pm 0.008$ & $3.03 \pm 0.15$ & $2.81 \pm 0.14$ & 0.2385 \\
\hline$L S D^{\dagger}$ & 1.0578 & 2.0012 & 0.6742 & \\
\hline
\end{tabular}

${ }^{(1)}$ Experiments were conducted on shake flasks as described in Materials and Methods section; ${ }^{*}$ Differences between data in the same row bigger than this LSD value are statistically significant; ${ }^{\dagger}$ Differences between data in the same column bigger than this LSD value are statistically significant. 


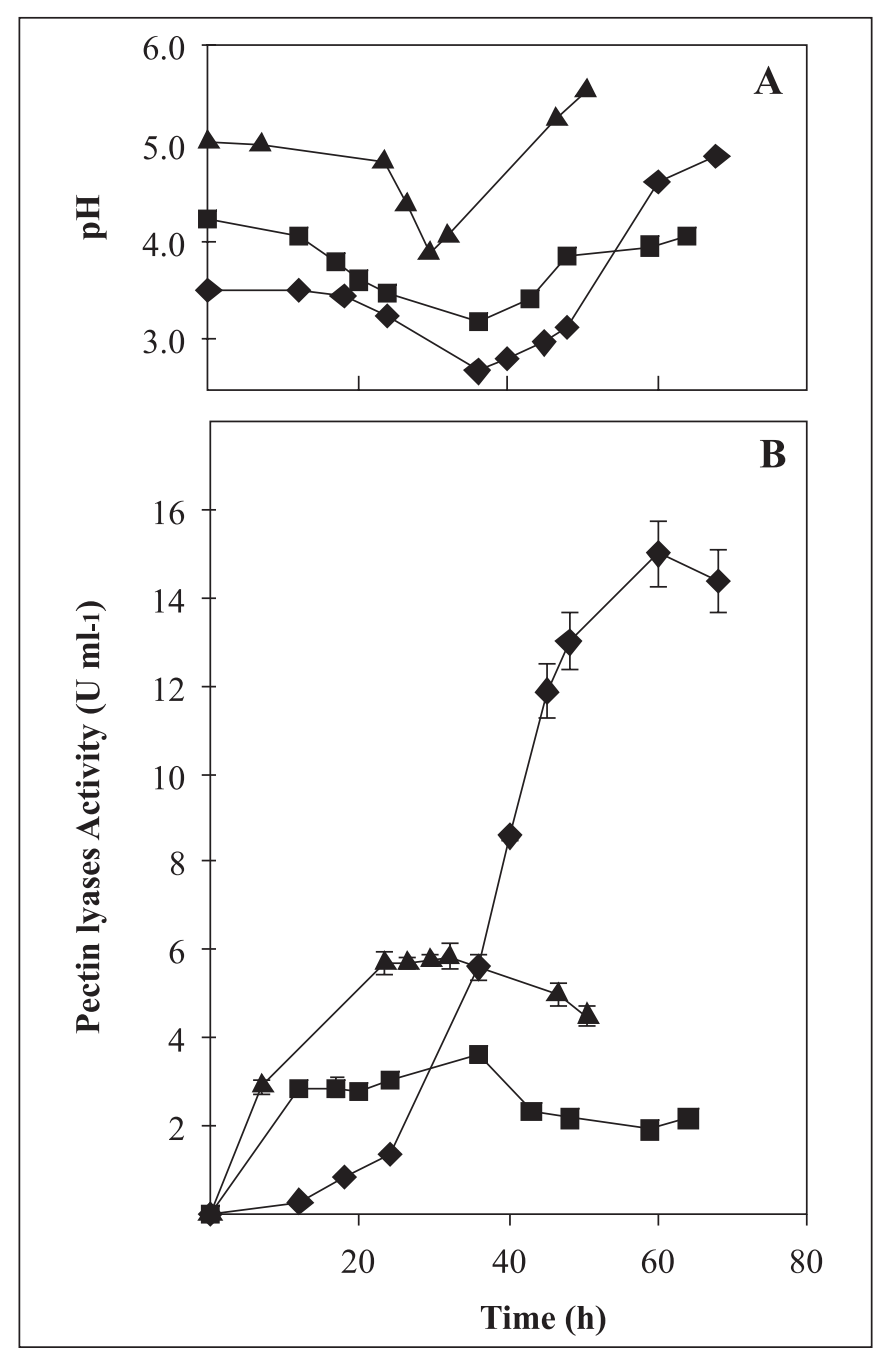

Figure 3. Evolution of $\mathrm{pH}$ (A) and PL activity (B) produced by Aspergillus flavipes FP-500 growing in a $5.0 \mathrm{~L}$ bioreactor with $10 \mathrm{~g}^{1^{-1}}$ of pectin, at initial pH of $3.5(\bullet), 4.2(\boldsymbol{\square})$ and $5.0(\boldsymbol{\Delta})$.

for rhamnose where the maximum productivity was attained at pH 4.2 (Table 1).

Concerning Endo-PG, enzymatic activity produced with simple sugars as carbon source was barely observed on galacturonic acid (Table 2). With xylose, arabinose and glucose very low levels $\left(<0.1 \mathrm{U} \mathrm{ml}^{-1}\right)$ of activity were found. However, these values are lower that the LSD, so it is not possible to make reliable a conclusion about these numbers, and in fact the activity produced with galacturonic acid is not conclusive at all. Endo-PG specific activity was significantly higher $\left(24.7 \mathrm{U} \mathrm{mg}^{-1}\right)$ on pectin with an initial $\mathrm{pH}$ of 3.5. Surprisingly, polygalacturonic acid was not a good carbon source (Table 2). It also should be highlighted that Endo-PG are produced in relatively high levels in a late culture stage ( $\sim 50 \mathrm{~h})$, after an earlier Exo-PG action on pectin.
Pectin lyase activity was observed in almost all substrates (Table 3). The lower specific activity was obtained when Aspergillus flavipes FP-500 was grown on glycerol and xylose (Table 3). A remarkable fact is that PL are present in all carbon sources, suggesting that this enzyme could probably be of a constitutive nature.

\section{DISCUSSION}

Growth and pectinase production by Aspergillus flavipes FP-500 were affected by the initial $\mathrm{pH}$ of culture medium (Fig. 1). Higher Exo- and Endo-polygalacturonase activities were obtained at 3.5 (Fig. 1). According to our results, A. flavipes FP500, produced in constitutive manner, basal levels of Exo-PG which starts to act on pectin, releasing reducing sugars to the medium. Afterwards, the reducing sugars produced trigger the massive production of Exo-PG. Therefore, it could be considered that these enzymes are also inducible to a certain level. The inducibility and constitutiveness of Exo-PG have been reported in other Aspergillus species $(1,3,8)$. The fact that Exo-PG was produced at early stages of fermentation allows a fast appearing of degradation products from pectin and the concomitant growth of the fungus (Fig. 1-3). Pectin degradation at this stage also provides inducers for Endo-PG and PL (Fig. 1-3). This is supported by the fact that Exo-PG is produced to different extent in different carbon sources (Table 1). It is possible to notice a trend to produce this activity by the fungus at lower $\mathrm{pH}$ (i.e. 3.5) but the most important thing is that activity was present in all cases. It is interesting that exo-activity produced on GalA and Gly was higher than those observed on the other simple sugars tested. However, from our results Exo-PG is considered a constitutive enzyme whereas GalA is proposed as inducer. On the other hand, in relation to Gly which is not part of pectin structure, it has recently been reported that in the catabolic pathway of galacturonic acid in Hypocrea jecorina (Trichoderma reesei), glycerol is obtained in the last stages of this route as a product of galacturonic acid degradation (10) and also that these catabolic pathway is conserved in A. niger. This could explain the relatively high productivities obtained on this carbon source. Induction of pectinases by GalA has been demonstrated in another Aspergillus species (23). Also it is an accepted fact that pectin and glycerol activate the expression of pectinases encoding genes on A. niger (4). However, it can not be discarded that Exo-PG respond also to the presence of Ara and Rha (Table 1).

The production of Endo-PG correlates with the reduction in the concentration of reducing groups at later time during fermentation (Fig. 2A and 2C) indicating control by catabolic repression, as it has been reported for several Aspergillus endopectinases (19). Unlike exo- activity, Endo-PG was only produced on pectin (Table 2) and the high productivity was found using pectin as carbon source. It was expected that this enzyme was produced also on polygalacturonic acid and eventually on GalA, 
but the activity produced on these carbon sources was negligible (Table 2). In both cases the productivity was lower than LSD, so is not possible to get reliable conclusions with this data. This is quite possible related to the evolution of the $\mathrm{pH}$ during culture. When pectin is used as carbon source the $\mathrm{pH}$ tend to decrease during the first hours of culture and to increase at later stages (Fig. 3). With glucose, xylose, arabinose, rhamnose and glycerol, the $\mathrm{pH}$ decreases, so that by the end of fermentation it reaches values between 2.2-2.8. However, with GalA and PGA, the $\mathrm{pH}$ behaved in the opposite way. The initial values in the culture medium tend to increase continuously reaching values of 6 to 7.5 , even when the initial $\mathrm{pH}$ is 3.5. This behavior has also been observed with Aspergillus flavus NRRL-2687 and CECT-6541 (Gomez-Sanchez and Aguilar, unpublished results).

Apart from this, as shown in the pectin experiments (Fig. 1), while initial $\mathrm{pH}$ increased, Endo-PG production was lower. So, in the case of GalA and PGA the lack of production of Endo-PG surely was due to the evolution of the $\mathrm{pH}$. These findings indicate that Endo-PG are truly inducible, and that pectin is the main inducer.

The lyases production with A. flavipes FP-500 occurred in practically all carbon sources with a trend to be produced at pH 5.0 (Table 3). Similar to Exo-PG, PL seems to be constitutive. The enzyme was produced at low level on different carbon sources but its production was stimulated by the presence of pectin and polygalacturonic acid. The constitutive expression of PL genes pelB, pelC and pelF has been reported in A. niger growing on a number of substrates, including glucose (3) and Penicillium griseoroseu was also reported to produce pectin lyases without any inducer (21). It is interesting to notice that this enzyme is only produced with PGA at pH 5.0, this fact reinforces the idea that the production of pectinases by this fungus is the result not only of initial $\mathrm{pH}$, but also of the evolution of this factor during culture.

As we discussed above, firstly, when A. flavipes was grown on PGA the $\mathrm{pH}$ tends to increase in spite of the initial value, but only when initial $\mathrm{pH}$ was set to 5.0 , pectin-lyase was produced.

Results obtained on bioreactor experiments seem to indicate an opposite behavior of the lyase production pattern in relation to $\mathrm{pH}$ (Fig. 3). In this experiment, higher activity was obtained at 3.5 (Fig. 3). Furthermore, the difference between the results in shaken flask and bioreactor experiments could be attributed to the difference in the availability of the dissolved oxygen in the medium. In addition, it has been reported that the capability of oxygen transfer in shaken flask, operated at conditions established in
Table 2. Endo-PG productivity of A. flavipes FP-500 in submerged culture using different carbon sources ${ }^{(1)}$.

\begin{tabular}{|c|c|c|c|c|}
\hline \multirow[t]{2}{*}{$\begin{array}{l}\text { Carbon } \\
\text { source }\end{array}$} & \multicolumn{4}{|c|}{$\begin{array}{c}P_{E X X}(\mathrm{U} / \mathrm{mg} \text { dry biomass }) \\
\text { Initial } \mathrm{pH}\end{array}$} \\
\hline & 3.5 & 4.2 & 5.0 & $L S D^{*}$ \\
\hline Arabinose & $0.13 \pm 0.004$ & 0.0 & 0.0 & 0.0013 \\
\hline Galacturonic acid & $0.50 \pm 0.025$ & 0.0 & 0.0 & 0.0500 \\
\hline Glucose & $0.052 \pm 0.004$ & 0.0 & 0.0 & 0.005 \\
\hline Glycerol & 0.0 & 0.0 & 0.0 & - \\
\hline Pectin & $24.7 \pm 1.24$ & $6.78 \pm 0.34$ & $1.67 \pm 0.08$ & 1.4804 \\
\hline $\begin{array}{l}\text { Polygalacturonic } \\
\text { acid }\end{array}$ & $0.22 \pm 0.011$ & 0.0 & $0.37 \pm 0.02$ & 0.0248 \\
\hline Rhamnose & 0.0 & 0.0 & 0.0 & - \\
\hline Xylose & 0.0 & $0.02 \pm 0.001$ & $0.006 \pm 0.0003$ & 0.0012 \\
\hline$L S D^{\dagger}$ & 0.7064 & 0.1938 & 0.0489 & \\
\hline
\end{tabular}

${ }^{(1)}$ Experiments were conducted on shake flasks as described in Materials and Methods section; * Differences between data in the same row bigger than this LSD value are statistically significant; ${ }^{\dagger}$ Differences between data in the same column bigger than this LSD value are statistically significant.

Table 3. PL productivity of A. flavipes FP-500 in submerged culture using different carbon sources ${ }^{(1)}$.

\begin{tabular}{lcccc}
\hline \multirow{1}{*}{\multicolumn{1}{c}{$\begin{array}{c}\text { Carbon } \\
\text { source }\end{array}$}} & \multicolumn{4}{c}{$P_{E / X}(\mathrm{U} / \mathrm{mg}$ dry biomass $)$} \\
& \multicolumn{4}{c}{ Initial pH } \\
\cline { 2 - 5 } & 3.5 & 4.2 & 5.0 & $L S D^{*}$ \\
\hline Arabinose & $1.37 \pm 0.04$ & $1.80 \pm 0.05$ & $0.22 \pm 0.006$ & 0.1046 \\
Galacturonic acid & $1.18 \pm 0.059$ & $0.93 \pm 0.0$ & $1.68 \pm 0.084$ & 0.1300 \\
Glucose & $4.36 \pm 0.04$ & $4.37 \pm 0.05$ & $6.01 \pm 0.006$ & 0.9896 \\
Glycerol & $0.65 \pm 0.0325$ & $0.29 \pm 0.015$ & $0.18 \pm 0.009$ & 0.0423 \\
Pectin & $2.79 \pm 0.14$ & $5.42 \pm 0.3$ & $5.20 \pm 0.11$ & 0.3738 \\
Polygalacturonic & 0.0 & 0.0 & $17.71 \pm 0.8$ & 1.7000 \\
acid & $1.73 \pm 0.09$ & $0.87 \pm 0.04$ & $0.45 \pm 0.023$ & 0.1147 \\
Rhamnose & $0.49 \pm 0.025$ & 0.0 & $2.27 \pm 0.11$ & 0.1339 \\
Xylose & 0.1643 & 0.2066 & 0.6903 & \\
$L S D^{\dagger}$ & &
\end{tabular}

${ }^{(1)}$ Experiments were conducted on shake flasks as described in Materials and Methods section; * Differences between data in the same row bigger than this LSD value are statistically significant; ${ }^{\dagger}$ Differences between data in the same column bigger than this LSD value are statistically significant.

our experiments, is enough to hold the fungal growth and pectinolytic enzyme production in non-limited oxygen conditions. In contrast, in the bioreactor experiments, oxygen was depleted quite soon, during the first $24 \mathrm{~h}$ of culture oxygen, tension (TOD) was practically cero for $\mathrm{pH} 4.2$ and 5.0 and it remained like that until the end of fermentation; whereas that 
for $\mathrm{pH} 3.5$ was around $20 \%$ at the same time. Therefore, cultures at $\mathrm{pH} 4.2$ and 5.0 were carried out under limited oxygen conditions. It is well known that the genus Aspergilli produces different kinds of organic acids in non-limited oxygen condition (TOD $>30 \%$ ) such as citric acid, gluconic acid, fumaric acid and kojic acid with the concomitant acidification of the culture medium. When the oxygen transfer rate is the limiting step in the fermentation, there is not accumulation of dissolved oxygen causing an important lack of oxygen which changes the metabolism. This could explain both the increase in $\mathrm{pH}$ of fermentation broth, and the stop of production of PL at initial $\mathrm{pH}$ values of 4.2 and 5.0. Furthermore, the relative rate of PL synthesis during the first hours of fermentation in bioreactor experiments were $0.0233,0.236$ and $0.321 \mathrm{Uml}-1 \mathrm{~h}-1$ for $3.5,4.2$ and $5.0 \mathrm{pH}$, respectively, indicating that the limiting step at this level was the dissolved oxygen tension (TOD) in the system.

\section{CONCLUSIONS}

Aspergillus flavipes FP-500 was able to grow and produce pectinase enzymes on different carbon sources at different initial $\mathrm{pH}$. Exo-PG and PL were produced constitutively and were also stimulated by the presence of inducer in the culture medium. Pectin, polygalacturonic acid and galacturonic acid were found to be effectors of the induction. According to our results, GalA or a product of its catabolism could be proposed as the real inducer of pectinolityc enzymes in this strain. In contrast, EndoPG was found to be basically inducible enzyme. Moreover, pectinases in A. flavipes FP-500 seem to be produced in a concerted way, according to the $\mathrm{pH}$ and to the available substrate. As a result, Exo-PG and PL were produced at the early stages of culture and Endo-PG at later.

Finally, as it has been discussed above, the production of these enzymes is not only related to the initial $\mathrm{pH}$ of culture medium, but also to it's evolution during fermentation.

\section{ACKNOWLEGEMENTS}

This work was financially supported by the projects IN207603 and IN219604 from DGAPA UNAM, and from SIPIPN. The authors acknowledge D. Aguilar Trejo, for helping with English language, E. Salgado for the critical reading of the manuscript and M.A. Ortiz for technical assistance.

\section{RESUMO}

\section{Enzimas pectinolíticas constitutivas e indutíveis de Aspergillus flavipes FP-500 e sua modulação pelo pH e fonte de carbono}

Avaliou-se o crescimento e a produção de enzimas por Aspergillus flavipes FP-500 em pectina, ácido poligalacturônico, ácido galacturônico, arabinose, ramnose, xilose, glicerol e glicose, em diferentes valores de $\mathrm{pH}$ inicial. Verificamos que a cepa produziu exopectinases, endopectinases e pectina liases. Exopectinases e pectina liases foram produzidas em níveis basais como enzimas constitutivas e sua produção foi modulada pela fonte de carbono disponível e pelo $\mathrm{pH}$ do meio de cultura e estimulada pela presença de indutores no meio de cultura. Endopectinase foi indutível e produzida somente quando pectina foi utilizada como fonte de carbono. Nossos resultados sugerem que as pectinases de A. flavipes FP-500 são produzidas de forma planejada. A primeira enzima a ser produzida foi expopectinase, seguida por pectina liase e endopectinase.

Palavras-chave: Aspergillus flavipes, enzimas pectinolíticas, enzimas constitutivas, enzimas indutíveis, pectina.

\section{REFERENCES}

1. Aguilar, G.; Huitrón C. (1990). Constitutive exo-pectinases produced by Aspergillus sp. CH-Y.1043 on different carbon sources. Biotechnol. Lett. 12, 655-660.

2. Crotti, L.B.; Terenzi, H.F.; Jorge, J.A.; Polizeli, M.L. (1998). Regulation of pectic enzymes from the exo-1 mutant strain of Neurospora crassa: effects of glucose, galactose and galaturonic acid. J. Basic Microb. 28(3), 181-188.

3. De Vries, R.P.; Jansen, J.; Aguilar, G.; Parenicova, L.; Joosten, V.; Wülfert, F.; Benen, J.A.; Visser, J. (2002). Expression profiling of pectinolytic genes from Aspergillus niger. FEBS Lett, 530, 41-47.

4. De Vries, R.P. (2003). Regulation of Aspergillus genes encoding plant cell wall polysaccharide-degrading enzymes, relevance for industrial production. Appl. Microbiol. Biotechnol. 61, 10-20.

5. De Vries, R.P.; Visser, J. (2001). Aspergillus enzymes involved in degradation of plant cell wall polysaccharides. Microbiol. Mol. Biol. Rev. 65(4), 497-552.

6. Delgado, L.; Trejo, A.B.; Huitrón, C.; Aguilar, G. (1993). Pectin lyase from Aspergillus sp. CH-Y-1043. Appl. Microbiol. Biotechnol. 39, 515-519.

7. Esquerré-Tugayé, M.T.; Boudart, G.; Dumas, B. (2000). Cell wall degrading enzymes, inhibitory proteins, and oligo-saccharides participate in the molecular dialogue between plants and pathogens. Plant Physiol. Biochem. 38(1-2), 157-163.

8. Fawolea, O.B.; Odunfab, S.A. (2003). Some factors affecting production of pectic enzymes by Aspergillus niger. Int. Biodeterior. Biodegradation. 52, 223-227.

9. Jayani, R.S.; Saxena, S.; Gupta, R. (2005). Microbial pectinolytic enzymes: A review. Process Biochem. 40(9), 2931-2944.

10. Kuorelahti, S.; Jouhten, P.; Maaheimo, H.; Penttila, M.; Richard, P. (2006). L-galactonate dehydratase is part of the fungal path for Dgalacturonic acid catabolism. Mol. Microbiol. 61(4), 1060-1068.

11. Lang, C.; Dörnenburg, H. (2000). Perspectives in the biological function and the technological application of polygalacturonases. Appl. Microbiol. Biotechnol. 53(4), 366-375.

12. Maccheroni, W.; Luiz Araujo, W.; Acevedo, L.J. (2004). Ambient $\mathrm{pH}$-regulated enzyme secretion in endophytic and pathogenic isolates of the fungal genus Colletotrichum. Sci Agric. 61(3), 298-302.

13. Mach, R.L.; Zeilinger, S. (2003). Regulation of gene expression in industrial fungi: Trichoderma. Appl Microbiol. Biotechnol. 60, 515522 .

14. Malvessi, E.; Moura da Silveira, M. (2004). Influence of medium composition and $\mathrm{pH}$ on the production of polygalacturonases by Aspergillus oryzae. Braz. Arch. Biol. Technol. 47(5), 693-702. 
15. Miller, G.L. (1959). Use of dinitrosalisylic acid (DNS) for determination of reducing sugars. Anal Chem. 31, 426-428.

16. Montgomery, D.C. (2001). Design and analysis of experiments. John Wiley \& Sons, New York.

17. Niture, S.K. (2008). Comparative biochemical and structura characterizations of fungal polygalacturonases. Biologia. 63(1), 1-19.

18. Olsson, L.; Christensen, T.M.I.E.; Hansen, K.M.; Palmqvist, E. (2003). Influence of the carbon source on production of cellulases, hemicellulases and pectinases by Trichoderma reesei Rut C-30. Enz. Microbiol. Technol. 33, 612-619.

19. Panda, T.; Sushma, R.N.; Prem, M.K. (2004). Regulation of synthesis of the pectolytic enzymes of Aspergillus niger. Enz. Microbiol. Technol. 34, 466-473.

20. Peñalva, M.; Arst, H. (2002). Regulation of gene expression by ambient $\mathrm{pH}$ in filamentous fungi and yeasts. Microbiol. Mol. Biol. Rev. 66(3), 426-446.

21. Piccoli-Valle, R.H.; Lopes, P.F.M.; Vieira, P.F.J.; Olzany, S.D. (2001). Production of pectin lyase by Penicillium griseoroseum in bioreactors in the absence of inducer. Braz. J. Microbiol. 32, 135-140.
22. Prade, R.A.; Zhan, D.; Ayoubi, P.; Mort, A.J. (1999). Pectins, pectinases and plant-microbe interactions. Biotechnol. Gen. Eng. Rev. 16, 361-391.

23. Runco, R.; Navarro, A.R.; Maldonado, M.C. (2001). Regulation of the production of polygalacturonase by Aspergillus terreus. World J. Microbiol. Biotechnol. 17, 487-491.

24. Teixeira, M.F.S.; Lima-Filho, J.L.; Durán, N. (2000). Carbon sources effect on pectinase production from Aspergillus japonicus 586 Braz. J. Microbiol. 31, 286-290.

25. Trejo-Aguilar, B.; Visser, J.; Aguilar-Osorio, G. (1996). Pectinase secretion by Aspergillus FP-180 and Aspergillus niger N402 growing under stress induced by the $\mathrm{pH}$ of culture medium. Proc. Pectin Pectinases Symp., p. 915-920.

26. Wubben, J.P.; Have, A.T.; van Kan, J.A.L.; Visser, J. (2000). Regulation of endopolygalacturonase gene expression in Botrytis cinerea by galacturonic acid, ambient $\mathrm{pH}$ and carbon catabolite repression. Curr. Gen. 37, 152-157. 